\title{
Interface-Engineered All-Solid-State Li-Ion Batteries Based on Garnet-Type Fast $\mathrm{Li}^{+}$Conductors
}

\author{
Jan van den Broek, Semih Afyon,* and Jennifer L. M. Rupp**
}

\begin{abstract}
All-solid-state $\mathrm{Li}$-ion batteries based on $\mathrm{Li}_{7} \mathrm{La}_{3} \mathrm{Zr}_{2} \mathrm{O}_{12}$ (LLZO) garnet structures require novel electrode assembly strategies to guarantee a proper $\mathrm{Li}^{+}$transfer at the electrode-electrolyte interfaces. Here, first stable cell performances are reported for $\mathrm{Li}$-garnet, $\mathrm{c}-\mathrm{Li}_{6.25} \mathrm{Al}_{0.25} \mathrm{La}_{3} \mathrm{Zr}_{2} \mathrm{O}_{12}$, all-solid-state batteries running safely with a full ceramics setup, exemplified with the anode material $\mathrm{Li}_{4} \mathrm{Ti}_{5} \mathrm{O}_{12}$. Novel strategies to design an enhanced $\mathrm{Li}^{+}$transfer at the electrode-electrolyte interface using an interface-engineered all-solid-state battery cell based on a porous garnet electrolyte interface structure, in which the electrode material is intimately embedded, are presented. The results presented here show for the first time that all-solid-state Li-ion batteries with LLZO electrolytes can be reversibly charge-discharge cycled also in the low potential ranges $(\approx 1.5 \mathrm{~V})$ for combinations with a ceramic anode material. Through a model experiment, the interface between the electrode and electrolyte constituents is systematically modified revealing that the interface engineering helps to improve delivered capacities and cycling properties of the all-solid-state Li-ion batteries based on garnet-type cubic LLZO structures.
\end{abstract}

\section{Introduction}

In the last years, rechargeable Li-ion batteries have become a staple in today's consumer electronics because they offer high volumetric and gravimetric energy densities compared to other battery technologies. ${ }^{[1]}$ Other advantages include their long cycle life and variable charge-discharge rates, giving them the potential to serve as primary storage for renewable energies in the future. ${ }^{[2]}$ Because of their high energy densities, Li-ion batteries are also the most promising technology for electric vehicles. ${ }^{[2]}$ However, to achieve a breakthrough in this sector the technology is not advanced enough yet to lower the manufacturing cost of battery systems for electric cars to make them available for everyone and to provide the range capability demanded by consumers. In order to boost battery capacities, most of the research concentrates on developing new electrode materials, in particular in combination

J. van den Broek, Prof. S. Afyon, Prof. J. L. M. Rupp ETH Zurich

Department of Materials

$\mathrm{CH}-8093$ Zurich, Switzerland

E-mail: semihafyon@iyte.edu.tr; jennifer.rupp@mat.ethz.ch

Prof. S. Afyon

Energy Systems Engineering

Izmir Institute of Technology

35430 Izmir, Turkey

DOI: 10.1002/aenm.201600736 with solid electrolytes. ${ }^{[3]}$ Solid electrolytes offer many advantages and could enable the use of new high capacity electrode materials such as sulfur, ${ }^{[4]}$ manganese, ${ }^{[5-7]}$ and vanadate ${ }^{[8,9]}$-based cathodes which may not be stable and safe in the current Li-ion battery technology based on liquid electrolytes. ${ }^{[10]}$ Furthermore, solid electrolytes have the promise to use directly metallic lithium anodes, i.e., preventing dendritic lithium growth, which enables even higher energy densities. From a practical point of view, one may also highlight that solid electrolytes have much-improved thermal operation windows resulting in a higher chemical and thermal stability, benefiting the long-term operation and safety when compared to their liquid counterparts. This allows for safe packaging of the cell geometries and enables miniaturized cell architectures while simultaneously reducing the battery weight. ${ }^{[11,12]}$

Among the oxide solid Li-ionic electrolytes, $\mathrm{Li}_{7} \mathrm{La}_{3} \mathrm{Zr}_{2} \mathrm{O}_{12}$ (LLZO) garnets and their doped variants show one of the highest Li-ion conductivities in the range of $\approx 10^{-4} \mathrm{~S} \mathrm{~cm}^{-1}$ at room temperature. ${ }^{[13]}$ LLZO was first synthesized and characterized in 2007 by Murugan et al. ${ }^{[14]}$ Not until a few years later Geiger et al. ${ }^{[15]}$ showed that LLZO appears in two different crystal structures, a cubic and a tetragonal one, with the cubic phase showing a Li-ion conductivity two orders of magnitude higher than the tetragonal phase. Using doping strategies, i.e., by introducing $\mathrm{Al}^{3+}, \mathrm{Ga}^{3+}, \mathrm{Ta}^{5+}, \mathrm{Nb}^{5+}$, etc., the high conductive cubic phase can be stabilized at room temperature by introducing vacancies into the Li sublattice of the structures. ${ }^{[16-19]}$ One of the most commonly used dopants is $\mathrm{Al}^{3+}$, which stabilizes the cubic phase by substituting for three $\mathrm{Li}^{+}$, thereby creating two Li vacancies and resulting in the stoichiometry of $\mathrm{Li}_{7-3 x} \mathrm{Al}_{x} \mathrm{La}_{3} \mathrm{Zr}_{2} \mathrm{O}_{12}$ for the cubic phase. ${ }^{[20]}$ Despite the promises, all-solid-state Li-ion batteries based on cubic LLZO solid electrolytes have still challenges in realizing high practical performances due to their high electrode-electrolyte interfacial resistances. For the investigations on all-solid-state batteries based on garnet-type cubic LLZO, most of the current research efforts are concentrated on the cathode material, most prominently on $\mathrm{LiCoO}_{2} \cdot{ }^{[21-27]}$ Reasonable electrochemical activities are so far only achieved by vacuum deposition of the cathode as thin films, i.e., by pulsed laser deposition (PLD), because of the resulting good electrolyte-electrode contact. ${ }^{[25,26]}$ Here, the exact chemical composition of the electrolyte-electrode interface also greatly determines the contact properties, the interfacial 
resistance and so the resulting battery performance. Kato et al. ${ }^{[22]}$ demonstrated that the formation of a diffusion layer during PLD deposition can result in a high interfacial resistance, which can be prevented by the deposition of an additional barrier layer, such as amorphous niobium metal at the interface, improving the cycling behavior of LLZO-based all-solidstate batteries. However, for the practical and cost-efficient construction of Li-ion batteries on larger scales, the direct casting of electrode powders, additives, and binders is required. Allsolid-state batteries based on LLZO with nonvacuum deposited cathodes revealed so far only limited performances, as shown for sol-gel deposited cathodes by Kotobuki et al. ${ }^{[27]}$ Introducing additives in either the electrolyte or the electrode can enable a cosintering/annealing step after nonvacuum electrode deposition, as demonstrated by Ohta et al., ${ }^{[21,24]}$ and improve the electrolyte-electrode contact properties, resulting in improved battery performance. However, depending on the electrode material, a cosintering step poses the risk of detrimental chemical reactions between the LLZO electrolyte and the electrode. Though different deposition techniques have been investigated in these aforementioned studies, importantly, the stability and applications of the garnet-type LLZO electrolytes against anode materials has so far not been demonstrated in literature yet. As dendrite formation in LLZO with Li metal anodes, especially at high current rates and lower pellet density, has been shown in literature, ${ }^{[28]}$ the investigation of alternative anode materials is also highly important. Here, we tackle these issues and report on all-solid-state Li-ion batteries of different designs, employing for the first time an anode material, i.e., $\mathrm{Li}_{4} \mathrm{Ti}_{5} \mathrm{O}_{12}$, combined with a low-temperature synthesized cubic $\mathrm{Li}_{6.25} \mathrm{Al}_{0.25} \mathrm{La}_{3} \mathrm{Zr}_{2} \mathrm{O}_{12}$ garnet-structure solid electrolyte. Based on literature, it can be suggested that combining anode materials to LLZO solid electrolyte for all-solid-state batteries is an important step, due to the following: (i) The main attention was so far placed on cathode materials, and the counterpart, i.e., the anode, is needed to realize full cells of LLZO-based all-solid-state batteries in future. (ii) Attention toward low-cost ceramic processing of commercially available electrode materials such as $\mathrm{Li}_{4} \mathrm{Ti}_{5} \mathrm{O}_{12}$ powders with the LLZO solid electrolyte pellets could allow for bottom up alternatives to expensive, volume-restricted thin film routes and open pathways to realistic implications of all-solid-state battery products based on Li-garnet structures. (iii) One can benefit to tune the interfacial electrode-electrolyte charge transfer in LLZO solid electrolyte-based batteries and infer on the electrochemical performance by direct comparison of the voltage plateau, stability, and performance to other standard polymer/ liquid cells based on same electrode material in the field.

In this work, we engineer material interfaces for all-solidstate batteries utilizing for the first time the anode material $\mathrm{Li}_{4} \mathrm{Ti}_{5} \mathrm{O}_{12}$ combined with the $\mathrm{c}-\mathrm{Li}_{6.25} \mathrm{Al}_{0.25} \mathrm{La}_{3} \mathrm{Zr}_{2} \mathrm{O}_{12}$ solid electrolyte. To implicate directly on the role of ceramic electrode/ electrolyte interface properties, we present two model cases of ceramic processing: First, the direct casting of the anode powder material and additives on dense c- $\mathrm{Li}_{6.25} \mathrm{Al}_{0.25} \mathrm{La}_{3} \mathrm{Zr}_{2} \mathrm{O}_{12}$ electrolyte pellets, and second, the processing of an electrode/ electrolyte composite forming a graded material structure with strong interconnectivity toward the electrolyte pellet. The electrochemical cells of such designs are tested with Limetal counter electrodes at $95{ }^{\circ} \mathrm{C}$, and we observe reversible charge-discharge behavior and stable cycling for the all-solidstate batteries under study. Importantly, the interface modification and graded anode material structure utilization toward the garnet-type $\mathrm{c}-\mathrm{Li}_{6.25} \mathrm{Al}_{0.25} \mathrm{La}_{3} \mathrm{Zr}_{2} \mathrm{O}_{12}$ electrolytes result in lowering of the resistance values. Here, the intimate embedding of nanograined $\mathrm{Li}_{4} \mathrm{Ti}_{5} \mathrm{O}_{12}$ into the solid electrolyte layer is satisfied through the engineering of the porous electrolyte surface by means of a sacrificial organic template, resulting in a good charge-transfer contact when subsequently coated with the electrode slurry. These novel interface-engineered batteries employing $\mathrm{Li}_{4} \mathrm{Ti}_{5} \mathrm{O}_{12}$ as an electrode material display superior electrochemical performance compared to the flat electrode/ electrolyte interfaces; viz., we report a discharge voltage plateau and cell potential against $\mathrm{Li}^{+} / \mathrm{Li}$ of $\approx 1.5 \mathrm{~V}$ close to theoretical and relatively stable cycling over 25 cycles. Finally, we discuss the direct implication of the interface-engineering between $\mathrm{Li}_{4} \mathrm{Ti}_{5} \mathrm{O}_{12}$ electrodes and $\mathrm{c}-\mathrm{Li}_{6.25} \mathrm{Al}_{0.25} \mathrm{La}_{3} \mathrm{Zr}_{2} \mathrm{O}_{12}$ garnet electrolytes in regard to future performances of all-solid-state batteries relative to current developments in the field.

\section{Results and Discussion}

The two model cases of all-solid-state batteries based on the garnet electrolyte structures c- $\mathrm{Li}_{6.25} \mathrm{Al}_{0.25} \mathrm{La}_{3} \mathrm{Zr}_{2} \mathrm{O}_{12}$ utilizing an anode material $\mathrm{Li}_{4} \mathrm{Ti}_{5} \mathrm{O}_{12}$ are presented as schematics in Figure 1. In the first model cell that will be denoted as "nonmodified all-solid-state battery", the composite electrode consisting of nanograined $\mathrm{Li}_{4} \mathrm{Ti}_{5} \mathrm{O}_{12}, \mathrm{c}-\mathrm{Li}_{6.25} \mathrm{Al}_{0.25} \mathrm{La}_{3} \mathrm{Zr}_{2} \mathrm{O}_{12}$ powder, PVDF (polyvinylidene fluoride), and conductive carbon particles is directly cast on a dense pellet of c- $\mathrm{Li}_{6.25} \mathrm{Al}_{0.25} \mathrm{La}_{3} \mathrm{Zr}_{2} \mathrm{O}_{12}$ with a flat polished surface. This represents a classic assembly of a ceramic electrode on the electrolyte, whereby a flat interface forms between the electrode and the electrolyte constituent. As a second model cell, referred to as "interface-engineered all-solid-state battery", we integrate for comparison the nanograined $\mathrm{Li}_{4} \mathrm{Ti}_{5} \mathrm{O}_{12}$-based electrode into the porous interface of a dense $\mathrm{c}-\mathrm{Li}_{6.25} \mathrm{Al}_{0.25} \mathrm{La}_{3} \mathrm{Zr}_{2} \mathrm{O}_{12}$ electrolyte pellet. In this way, the potential to decrease the interfacial resistance for contacting and embedding of the composite electrode into the solid electrolyte can be studied for the all-solid-state batteries. Here, the interface engineering is achieved through the employment of a sacrificial organic template on dense $\mathrm{c}-\mathrm{Li}_{6.25} \mathrm{Al}_{0.25} \mathrm{La}_{3} \mathrm{Zr}_{2} \mathrm{O}_{12}$ pellets, resulting in a porous interface after sintering into which the electrode slurry is cast. We will use metallic Li as counter electrode in both cell models with titanium current collectors on each electrode side, see Figure 1.

For both battery cell assemblies, the utilization of low-dimensional c- $\mathrm{Li}_{6.25} \mathrm{Al}_{0.25} \mathrm{La}_{3} \mathrm{Zr}_{2} \mathrm{O}_{12}$ particles in terms of size is crucial to ensure a good physical contact between the nanograined electrode and electrolyte constituents, resulting in a good ionic conduction in the composite electrode and over the electrodeelectrolyte interface. Here, we use in a first step a modified sol-gel synthesis-combustion method to synthesize such lowdimensional particles of $\mathrm{c}-\mathrm{Li}_{6.25} \mathrm{Al}_{0.25} \mathrm{La}_{3} \mathrm{Zr}_{2} \mathrm{O}_{12}$, which are subsequently sintered to dense pellets. The XRD (X-ray diffraction) powder patterns for both are being displayed in Figure 2a: The figure shows the reference cubic phase LLZO (ICSD 182312 ${ }^{[29]}$ ), the calcined gel-powder after calcination at $650{ }^{\circ} \mathrm{C}$ and a 


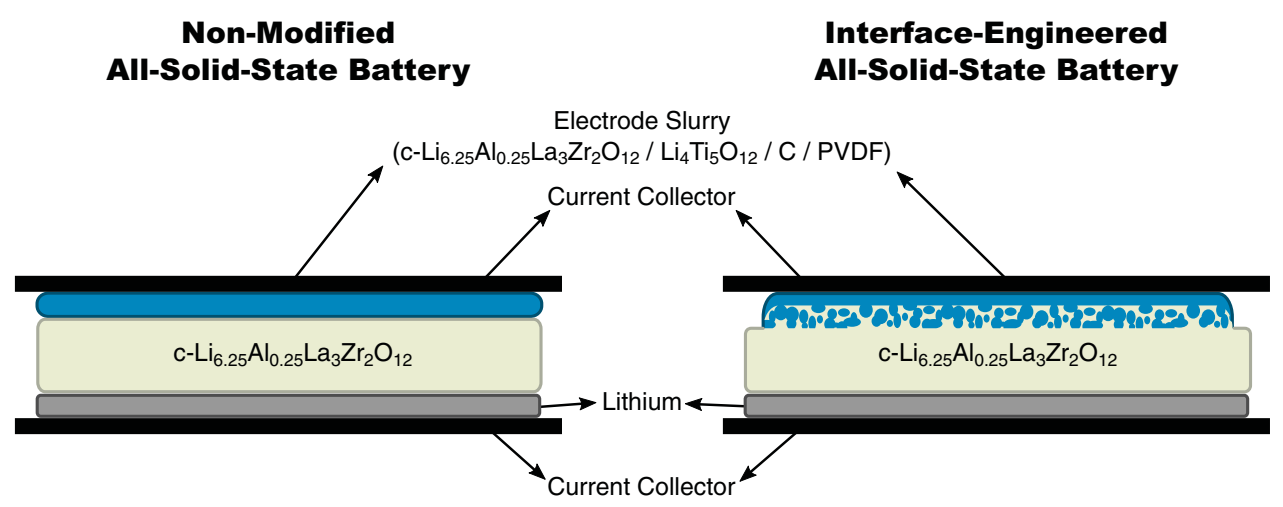

Figure 1. Schematic drawing of a) nonmodified all-solid-state battery and b) interface-engineered all-solid-state battery based on c-Li ${ }_{6.25} \mathrm{Al}_{0.25} \mathrm{La}_{3} \mathrm{Zr}_{2} \mathrm{O}_{12}$ solid electrolyte, and $\mathrm{Li}_{4} \mathrm{Ti}_{5} \mathrm{O}_{12}$ and $\mathrm{Li}$-metal electrodes.

crushed pellet after sintering at $1075{ }^{\circ} \mathrm{C}$. After calcination the cubic phase c- $\mathrm{Li}_{6.25} \mathrm{Al}_{0.25} \mathrm{La}_{3} \mathrm{Zr}_{2} \mathrm{O}_{12}$ is obtained with minute amounts of residual tetragonal phase in accordance to the reference ICSD $246816^{[30]}$ pattern. This shows that after calcination at only $650{ }^{\circ} \mathrm{C}$, most of $\mathrm{Al}^{3+}$ is incorporated into the garnet framework, leading to the successful stabilization of the cubic phase. Peak broadening in the XRD (powder patterns of c- $\mathrm{Li}_{6.25} \mathrm{Al}_{0.25} \mathrm{La}_{3} \mathrm{Zr}_{2} \mathrm{O}_{12}$ obtained at $650{ }^{\circ} \mathrm{C}$ indicates the lowdimensional character of the particles. Further temperature increase and sintering of pellets pressed from this powder at $1075{ }^{\circ} \mathrm{C}$ for $10 \mathrm{~h}$ reveals the single cubic phase of c- $\mathrm{Li}_{6.25} \mathrm{Al}_{0.25} \mathrm{La}_{3} \mathrm{Zr}_{2} \mathrm{O}_{12}$. The XRD powder patterns also show that the annealed powders and sintered pellets do not contain any additional impurities. The phase purity and formation is in good agreement to earlier reports where Al-doped LLZO was stabilized in its cubic phase. ${ }^{[31-33]}$ In a next step, the sintering characteristics of the synthesized c- $\mathrm{Li}_{6.25} \mathrm{Al}_{0.25} \mathrm{La}_{3}$ $\mathrm{Zr}_{2} \mathrm{O}_{12}$ powders are studied after their calcination, Figure $2 \mathrm{~b}$,

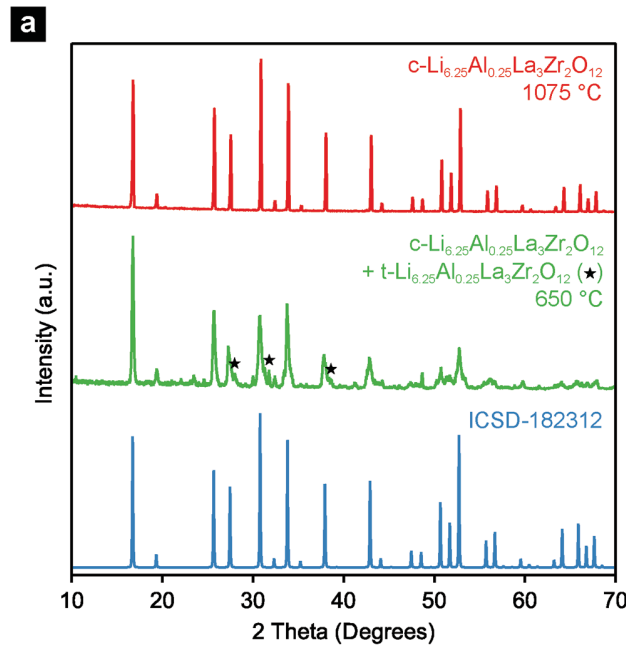

b
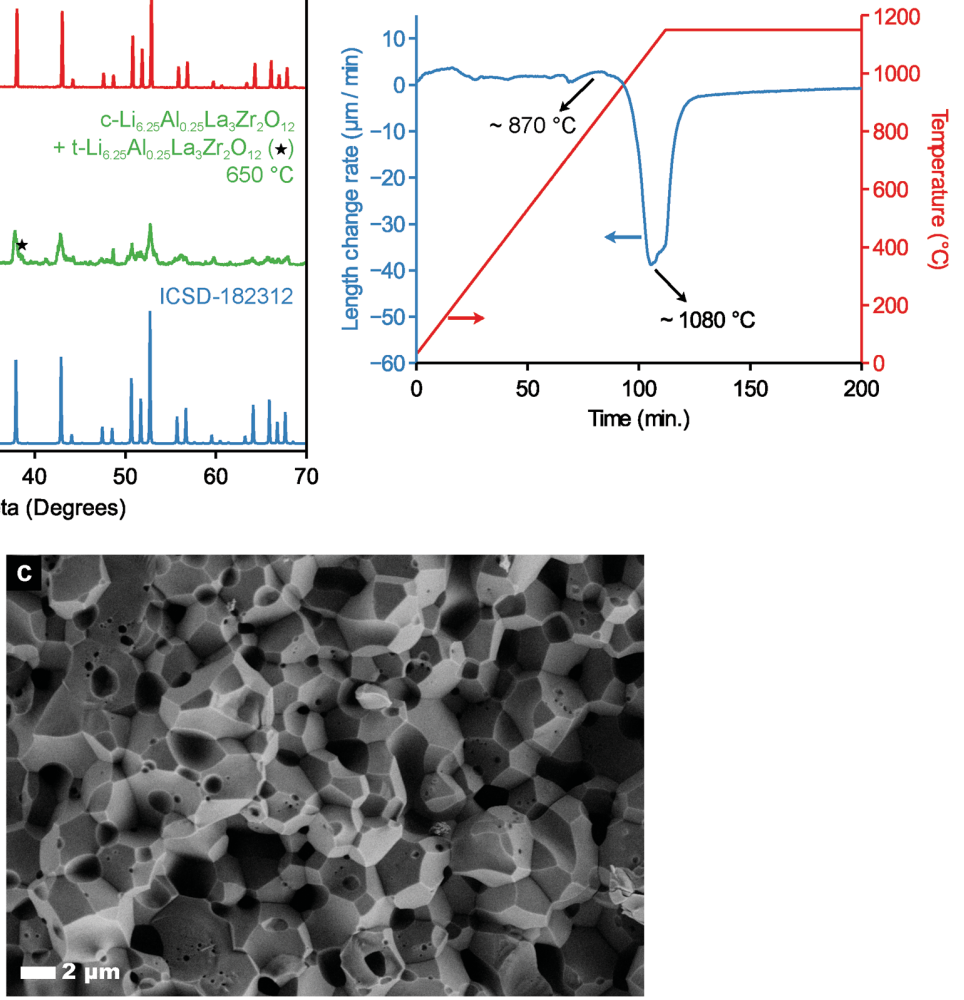

Figure 2. a) XRD powder patterns of calculated $\mathrm{c}-\mathrm{Li}_{7} \mathrm{La}_{3} \mathrm{Zr}_{2} \mathrm{O}_{12}$ (blue) and $\mathrm{c}-\mathrm{Li}_{6.25} \mathrm{Al}_{0.25} \mathrm{La}_{3} \mathrm{Zr}_{2} \mathrm{O}_{12}$ after calcination (green) and after sintering (red), respectively. b) The differential dilatometry plot of a c- $\mathrm{Li}_{6.25} \mathrm{Al}_{0.25} \mathrm{La}_{3} \mathrm{Zr}_{2} \mathrm{O}_{12}$ green body pellet heated with a constant rate of $10{ }^{\circ} \mathrm{C}$ min ${ }^{-1}$ showing the main sintering characteristics. c) SEM image of a pellet cross-section of c- $\mathrm{Li}_{6.25} \mathrm{Al}_{0.25} \mathrm{La}_{3} \mathrm{Zr}_{2} \mathrm{O}_{12}$. 
via differential dilatometry. We observe in the dilatometry characteristics of the $c-\mathrm{Li}_{6.25} \mathrm{Al}_{0.25} \mathrm{La}_{3} \mathrm{Zr}_{2} \mathrm{O}_{12}$ powders pressed to a green body pellet that the onset of sintering, indicated by a negative length change rate, can already be seen at a temperature of $\approx 870{ }^{\circ} \mathrm{C}$ for heating with a constant rate of $10^{\circ} \mathrm{C} \mathrm{min}{ }^{-1}$. The peak minimum indicates the main sintering event at a temperature of $\approx 1080^{\circ} \mathrm{C}$. In comparison to dilatometry results of cubic LLZO published in literature, the onset of sintering is lowered by about $250{ }^{\circ} \mathrm{C} \cdot{ }^{[33,34]}$ Dilatometry studies performed by the group of Doeff and co-workers ${ }^{[34]}$ on Al-substituted LLZO synthesized by solid-state methods revealed that a reduction in particle size from 10 to $1 \mu \mathrm{m}$ by attrition milling lowers the onset temperature for sintering by $\approx 130^{\circ} \mathrm{C}$ and increases the density of sintered pellets. This is attributed to the larger surface and thus larger contact area between crystallites. In comparison to LLZO powders processed by solid-state ${ }^{[31,34-36]}$ and sol-gel synthesis, ${ }^{[19]}$ scanning electron microscopy (SEM) images of ascalcined c- $\mathrm{Li}_{6.25} \mathrm{Al}_{0.25} \mathrm{La}_{3} \mathrm{Zr}_{2} \mathrm{O}_{12}$ powders processed through the modified sol-gel synthesis-combustion method in this study revealed smaller particle sizes of $1 \mu \mathrm{m}$ to $200 \mathrm{~nm}$, see Figure S2 (Supporting Information). This results in a rather high surface area which can explain the substantially lowered sintering temperature. We achieve through the low temperature synthesis of $\mathrm{c}-\mathrm{Li}_{6.25} \mathrm{Al}_{0.25} \mathrm{La}_{3} \mathrm{Zr}_{2} \mathrm{O}_{12}$ powders and subsequent sintering relative densities up to $(90 \pm 3) \%$ for pellets sintered at $1070{ }^{\circ} \mathrm{C}$ while maintaining the cubic phase, which is a prerequisite for the subsequent battery cell assemblies. SEM images of sintered c- $\mathrm{Li}_{6.25} \mathrm{Al}_{0.25} \mathrm{La}_{3} \mathrm{Zr}_{2} \mathrm{O}_{12}$ pellet cross-sections were taken to further investigate their grain size and morphology after sintering, see Figure 2c. c- $\mathrm{Li}_{6.25} \mathrm{Al}_{0.25} \mathrm{La}_{3} \mathrm{Zr}_{2} \mathrm{O}_{12}$ pellets sintered at $1070^{\circ} \mathrm{C}$ for $10 \mathrm{~h}$ show very good intergrain connectivity with an average grain size of $\approx 1-4 \mu \mathrm{m}$. Excitingly, this is much smaller in comparison to the $20-200 \mu \mathrm{m}$ large grains reported in literature for Al-doped LLZO sintered at comparable temperatures of $\approx 1100{ }^{\circ} \mathrm{C} \cdot[34,36,37]$ Energy dispersive X-ray (EDX) spectra obtained from the sintered pellet cross-sections reveal that $\mathrm{Al}^{3+}$ is homogeneously distributed throughout sintered pellets, see Figure S3 (Supporting Information).
The ionic conductivity of low temperature synthesized-processed c- $\mathrm{Li}_{6.25} \mathrm{Al}_{0.25} \mathrm{La}_{3} \mathrm{Zr}_{2} \mathrm{O}_{12}$ was determined by AC impedance spectroscopy of sintered pellets with attached symmetrical Pt electrodes. Similar pellet assemblies have been tested against Li in the work by Buschmann et al. ${ }^{[38]} \mathrm{A}$ typical Nyquist plot of a c- $\mathrm{Li}_{6.25} \mathrm{Al}_{0.25} \mathrm{La}_{3} \mathrm{Zr}_{2} \mathrm{O}_{12}$ pellet measured at room temperature by electrochemical impedance spectroscopy is displayed in Figure 3a. The impedance data were fitted with an equivalent circuit of the form $\left(R_{\text {bulk }}\right)\left(R_{\mathrm{gb}} Q_{\mathrm{gb}}\right)\left(Q_{\text {electrode }}\right)$, denoting bulk resistance, grain boundary resistance and capacitance, and double layer capacitance from the ion blocking electrodes. Constant phase elements $(Q)$ were used for the fit. The measurements showed an offset of the impedance response at high frequencies, a semicircle for intermediate frequencies, and a tail for high frequencies. We attribute these to bulk resistance, grain boundary resistance, and double layer capacitance from ion blocking electrodes, respectively. ${ }^{[3]]}$ The Arrhenius plot of a dense c- $\mathrm{Li}_{6.25} \mathrm{Al}_{0.25} \mathrm{La}_{3} \mathrm{Zr}_{2} \mathrm{O}_{12}$ pellet ( $\approx 87 \%$ density) measured under Ar atmosphere, both for heating and subsequent cooling, is shown in Figure 3b. Notably, a high ionic conductivity of $0.5 \times 10^{-3} \mathrm{~S} \mathrm{~cm}^{-1}$ (bulk) at ambient temperature and an activation energy for bulk Li-ionic conductivity of $0.28 \pm 0.1 \mathrm{eV}$ is determined for the low temperature synthesized c- $\mathrm{Li}_{6.25} \mathrm{Al}_{0.25} \mathrm{La}_{3} \mathrm{Zr}_{2} \mathrm{O}_{12}$, which is in good agreement with the literature. ${ }^{[14,31,33,40-43]}$

Based on the successful processing of the $c-\mathrm{Li}_{6.25} \mathrm{Al}_{0.25} \mathrm{La}_{3} \mathrm{Zr}_{2} \mathrm{O}_{12}$ electrolyte pellets, we now use these as a template to build up the two model battery cells based on $\mathrm{Li}_{4} \mathrm{Ti}_{5} \mathrm{O}_{12}$ electrodes and the well conducting c- $\mathrm{Li}_{6.25} \mathrm{Al}_{0.25} \mathrm{La}_{3} \mathrm{Zr}_{2} \mathrm{O}_{12}$ garnet electrolyte. We first turn to the top surfaces of the nonmodified and interface-engineered $\mathrm{c}-\mathrm{Li}_{6.25} \mathrm{Al}_{0.25} \mathrm{La}_{3} \mathrm{Zr}_{2} \mathrm{O}_{12}$ templates without any electrodes: Here, Figure $4 \mathrm{a}, \mathrm{b}$ displays SEM images of sintered pellet surfaces, respectively. First, the nonmodified c- $\mathrm{Li}_{6.25} \mathrm{Al}_{0.25} \mathrm{La}_{3} \mathrm{Zr}_{2} \mathrm{O}_{12}$ pellets without any interface engineering show a flat and dense surface microstructure, see Figure 4a and Figure S4 (Supporting Information). In comparison, the interface-engineered pellet shows a porous surface with irregular pores of sizes around $10-30 \mu \mathrm{m}$ as depicted in Figure $4 \mathrm{~b}$. This finding shows that
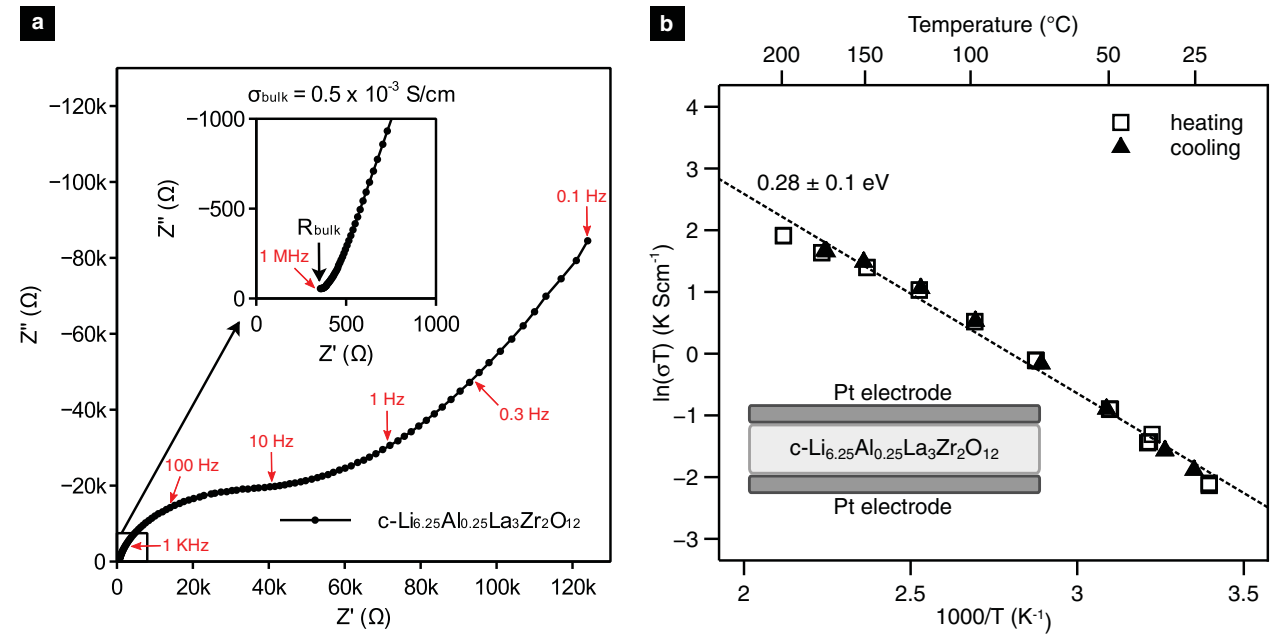

Figure 3. a) Nyquist plot of a c- $\mathrm{Li}_{6.25} \mathrm{Al}_{0.25} \mathrm{La}_{3} \mathrm{Zr}_{2} \mathrm{O}_{12}$ pellet with Pt electrodes measured at room temperature. b) Arrhenius plot for heating and cooling

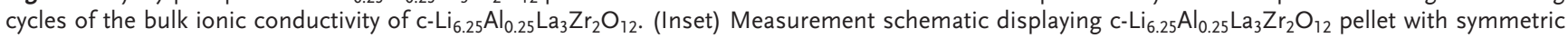
platinum electrodes. 


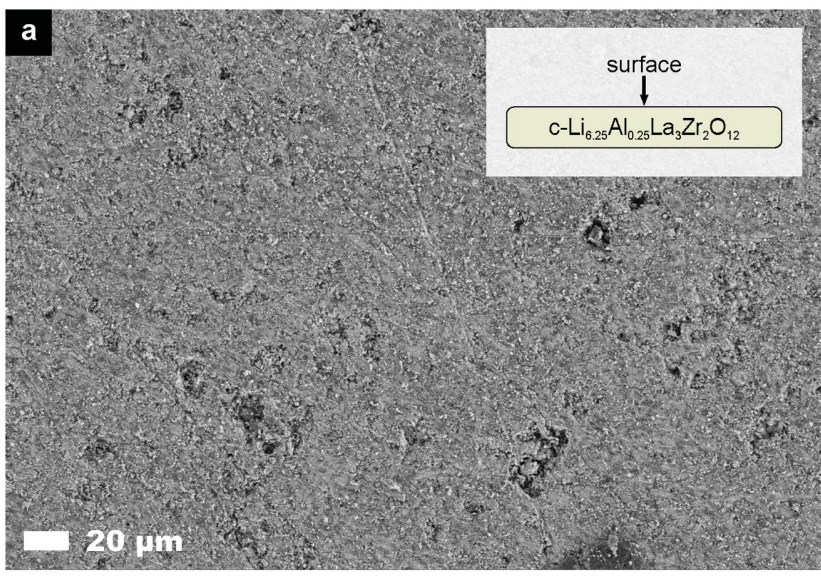

c

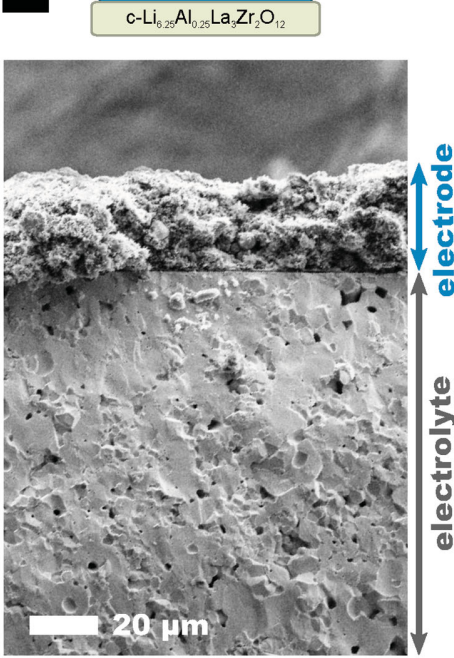

d

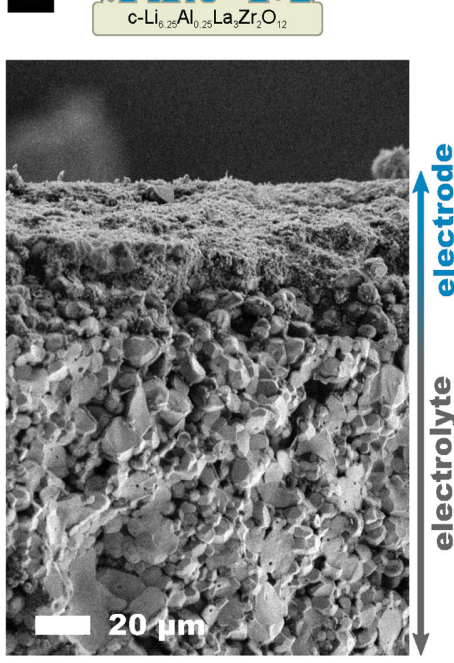

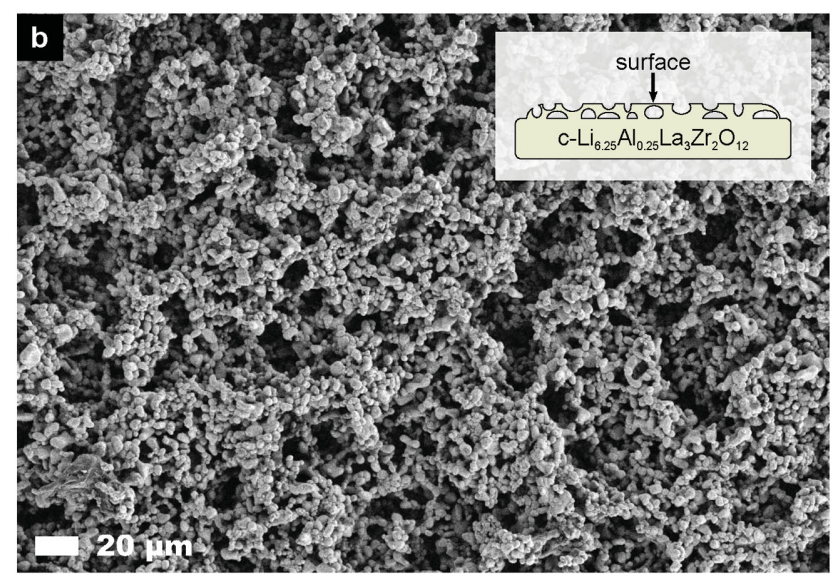

e

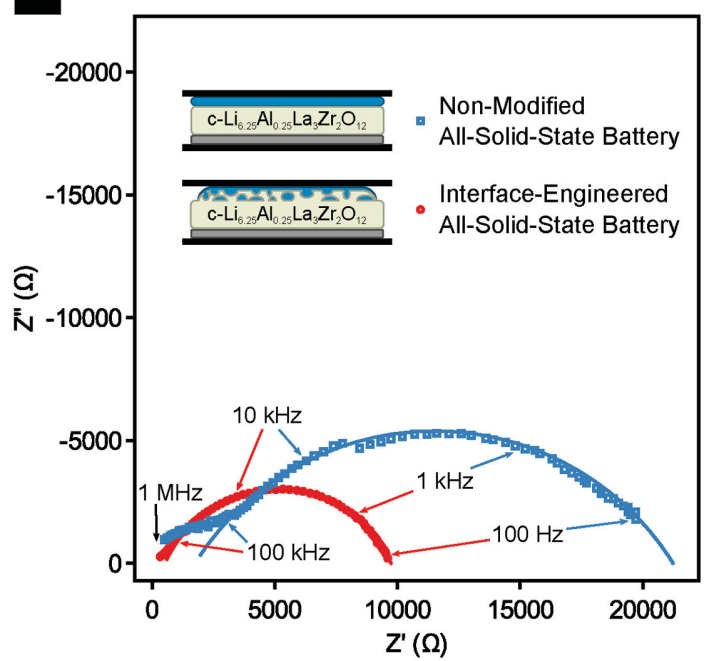

Figure 4. a,b) SEM images of a) nonmodified pellet surface and b) interface-engineered pellet surface. c,d) SEM images of sintered pellet cross-sections with composite nano- $\mathrm{Li}_{4} \mathrm{Ti}_{5} \mathrm{O}_{12}$ electrodes for (c) nonmodified and (d) interface-engineered pellets. e) Nyquist plots of nonmodified (blue) and interface-engineered (red) all-solid-state batteries based on $\mathrm{c}-\mathrm{Li}_{6.25} \mathrm{Al}_{0.25} \mathrm{La}_{3} \mathrm{Zr}_{2} \mathrm{O}_{12}$ with nanograined $\mathrm{Li}_{4} \mathrm{Ti}_{5} \mathrm{O}_{12}$ and $\mathrm{Li}$-metal electrodes measured at $95{ }^{\circ} \mathrm{C}$.

interface-engineered pellets have a considerably increased surface area with a network of open pores. The engineered interface thickness is in the range of $\approx 25 \mu \mathrm{m}$ in average, as revealed by the cross section SEM images of the model templates, Figure S4 (Supporting Information).

In a next step, the two model designs of all-solid-state batteries with casted composite electrodes utilizing nanograined $\mathrm{Li}_{4} \mathrm{Ti}_{5} \mathrm{O}_{12}$ are investigated in their cross-sections by SEM images as shown in Figure 4c,d. For the nonmodified all-solid-state battery, the dense electrolyte pellet can be clearly distinguished from the $\approx 25 \mu \mathrm{m}$ thick electrode layer on top with a sharp interface in-between, see Figure 4c. In contrast, for the interface-engineered all-solid-state battery, the electrode layer is intimately embedded into the porous layer of the electrolyte pellet, giving a graded electrolyte-electrode transition; see Figure $4 \mathrm{~d}$ and Figure S5 (Supporting Information) for a more detailed marking of the individual layer thicknesses of the electrode and electrolyte constituents. Importantly, no clear division line can be distinguished anymore between the solid electrolyte and electrode for the case of the interface-engineered all-solid-state battery. Although the interface-engineered pellet has a lower density compared to the nonmodified pellet in the example shown here ( $90 \%$ vs $87 \%$ relative densities, respectively), the difference in the electrolyte-electrode interface is evident for the two different all-solid-state battery assemblies.

We now use AC impedance spectroscopy for both cell assemblies to study the impact of the electrode-electrolyte interface microstructure engineering on the electrochemical impedances, see Figure 4e. The direct comparison of the impedance response for both model cells further reveals the reduced resistance values and enhanced electrochemical properties of the interface-engineered all-solid-state batteries based on c- $-\mathrm{Li}_{6.25} \mathrm{Al}_{0.25} \mathrm{La}_{3} \mathrm{Zr}_{2} \mathrm{O}_{12}$ garnet electrolytes. The semicircles observed in Nyquist plots of cells were fitted with an equivalent circuit of a resistor and a constant phase element in parallel and the outer intersection of the semicircle with the real axis could be estimated as the total resistance of the cell. As evidenced by the measurement, the resistance values for interfaceengineered full cells were considerably reduced by more than a factor of two compared to nonmodified cells. For the given cell geometry and temperature range tested in, a clear separation by impedance and equivalent circuits of the many different 
a

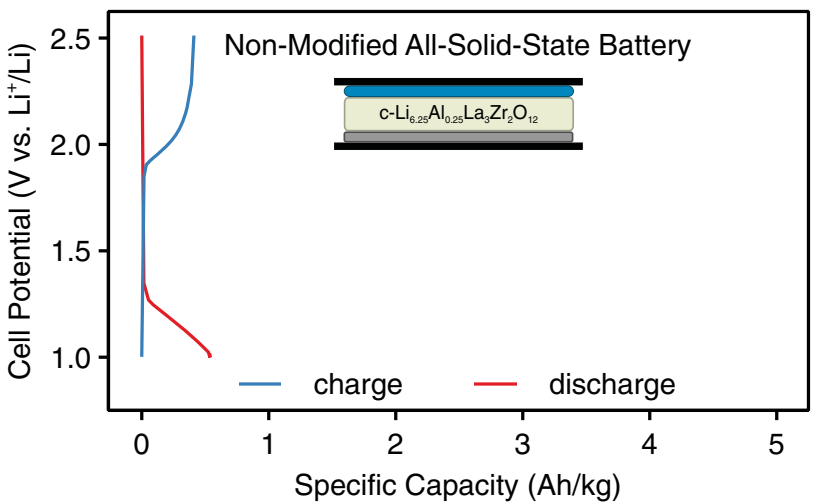

b

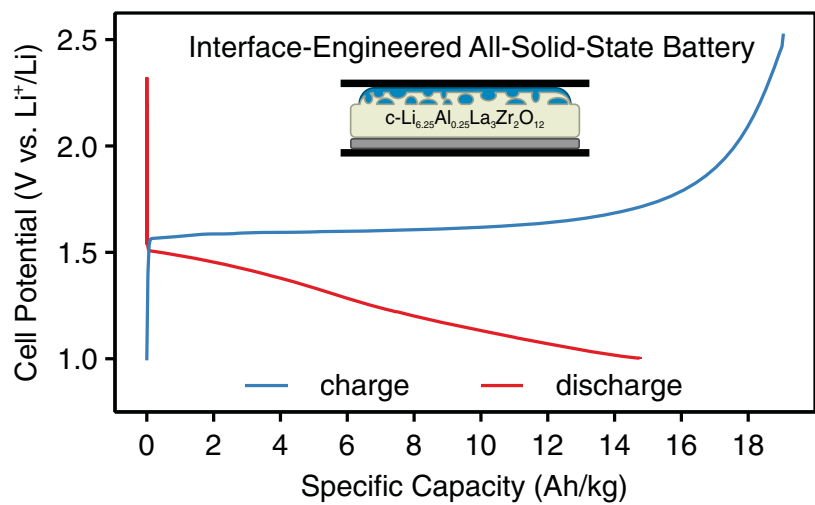

c

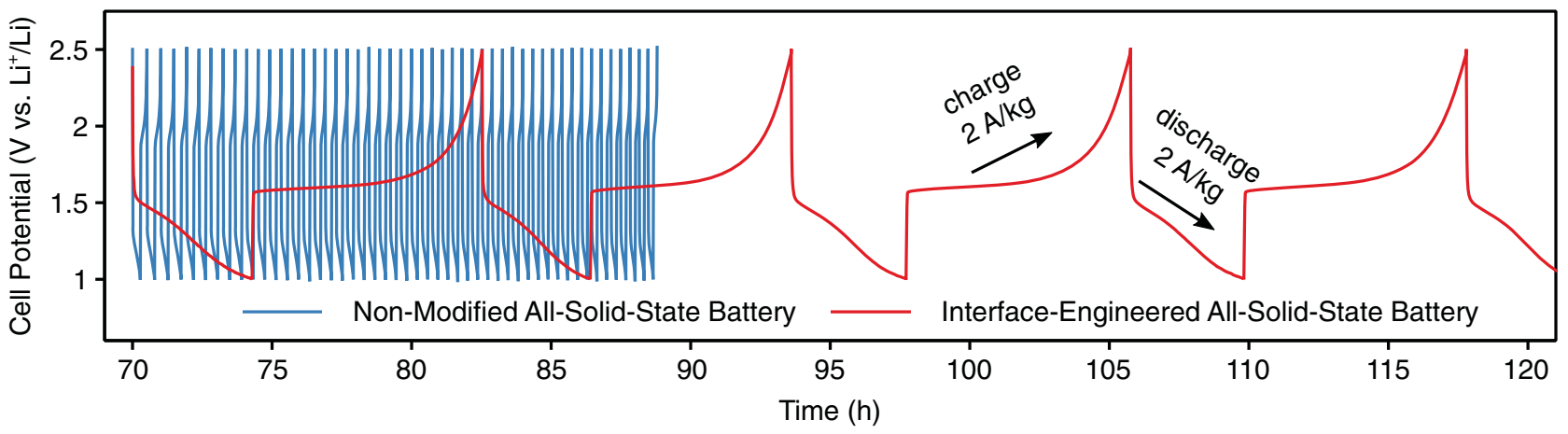

d

e
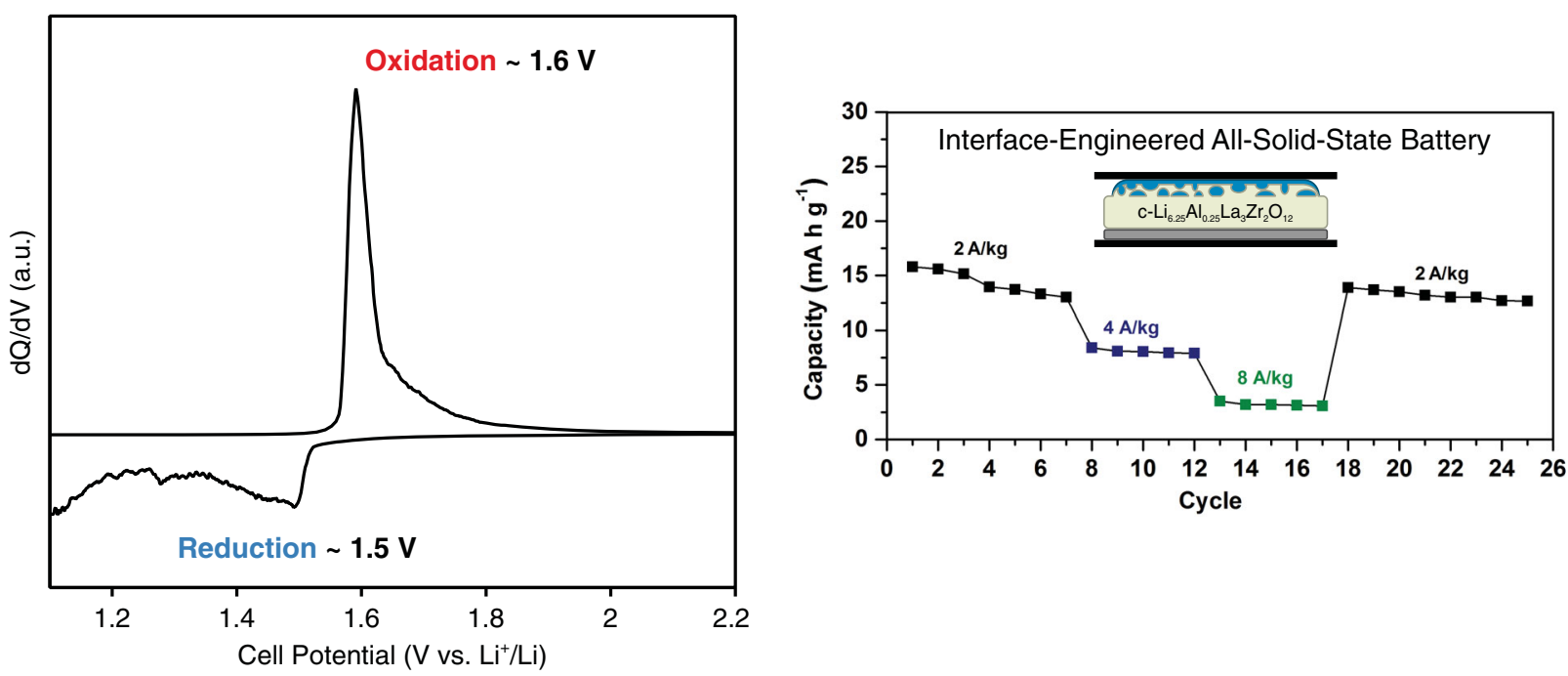

Figure 5. Electrochemical tests for all-solid-state batteries with c- $\mathrm{Li}_{6.25} \mathrm{Al}_{0.25} \mathrm{La}_{3} \mathrm{Zr}_{2} \mathrm{O}_{12}$ solid electrolyte, $\mathrm{Li}_{4} \mathrm{Ti}_{5} \mathrm{O}_{12}$, and $\mathrm{Li}$-metal electrodes cycled at $95{ }^{\circ} \mathrm{C}$ between 1.0 and $2.5 \mathrm{~V}$ at a current rate of $2 \mathrm{~A} \mathrm{~kg}^{-1}$ : a,b) Galvanostatic charge/discharge curves for (a) nonmodified and (b) interface-engineered allsolid-state batteries, showing cell potential versus specific capacity. c) Cell potential versus time for multiple charge/discharge cycles for nonmodified (blue) and interface-engineered all-solid-state batteries (red). d) dQ/dV plot of an interface-engineered all-solid-state battery showing clearly defined oxidation and reduction peaks. e) Rate capability of an interface-engineered all-solid-state battery at 2, 4, and $8 \mathrm{~A} \mathrm{~kg}^{-1}$ current rates within $1.0-2.5 \mathrm{~V}$.

elements contributing to the total impedance (e.g., $\mathrm{Li}_{4} \mathrm{Ti}_{5} \mathrm{O}_{12}$ and its carbon coating, c- $\mathrm{Li}_{6.25} \mathrm{Al}_{0.25} \mathrm{La}_{3} \mathrm{Zr}_{2} \mathrm{O}_{12}$, PVDF, active carbon, etc.) is not possible due to overlap of the individual impedance arcs. As the main sole difference between both samples is the interface engineering, the decrease in the overall resistance values can be directly attributed to the interface modification. In addition, the interface-engineered all-solid-state batteries mostly showed complete semicircles in their Nyquist 

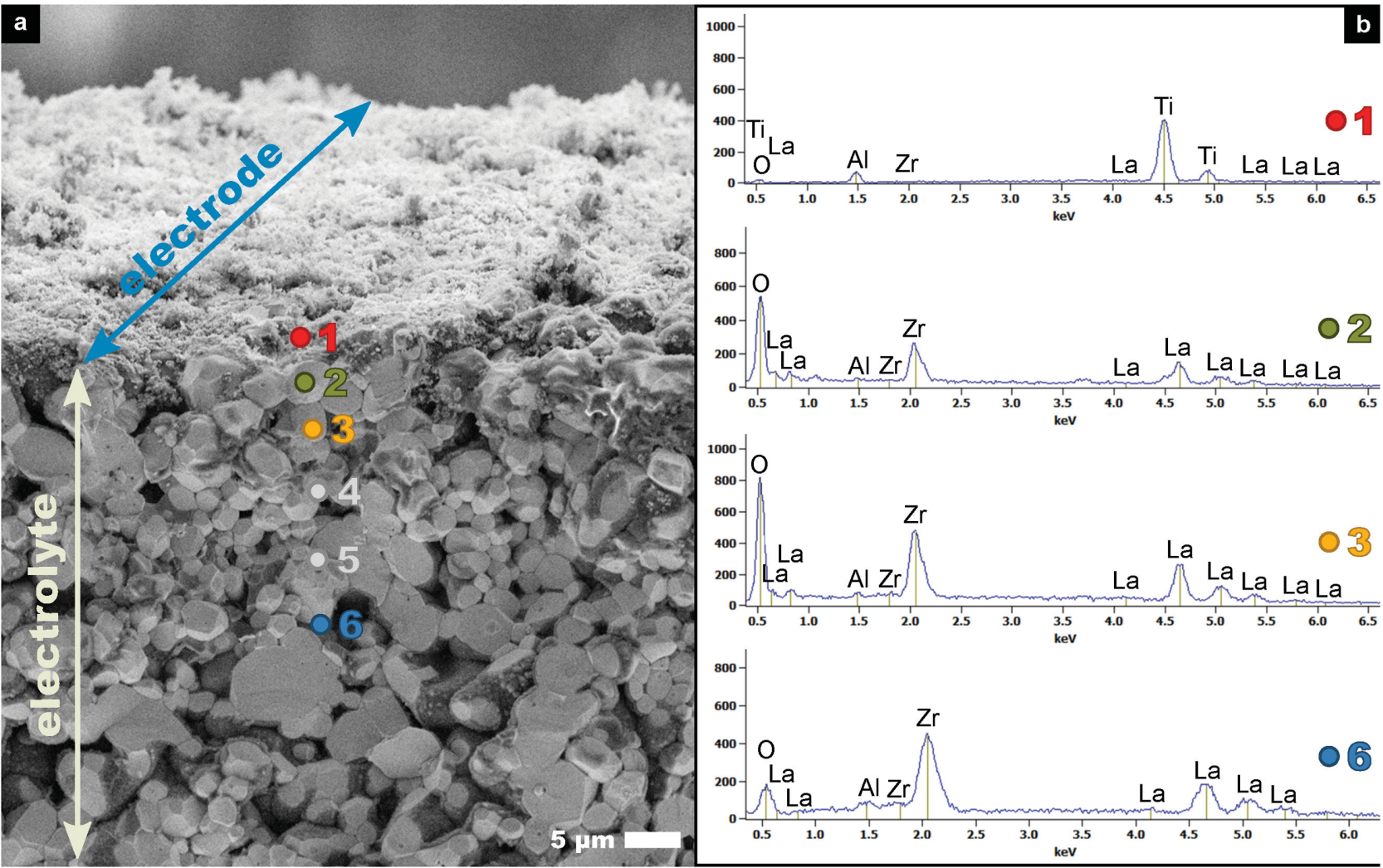

Figure 6. a) SEM image from an interface-engineered all-solid-state battery based on c- $\mathrm{Li}_{6.25} \mathrm{Al}_{0.25} \mathrm{La}_{3} \mathrm{Zr}_{2} \mathrm{O}_{12}$ and nanograined $\mathrm{Li}_{4} \mathrm{Ti}_{5} \mathrm{O}_{12}$ electrode obtained after 25 charge/discharge cycles, displaying the solid electrolyte and the electrode surface. b) Energy-dispersive X-ray spectra (EDX) data from the marked regions in (a), confirming that no new phases containing the transition metal (Ti) can be found at the electrode-electrolyte interphase (marked spots of 2, 3, 4, 5, and 6).

plots demonstrating nonblocking behavior for the electrodes. The reduced resistances observed for the interface-engineered all-solid-state batteries based on c- $\mathrm{Li}_{6.25} \mathrm{Al}_{0.25} \mathrm{La}_{3} \mathrm{Zr}_{2} \mathrm{O}_{12}$ garnet electrolytes was encouraging to further continue with galvanostatic cycling of cells, which allows an insight into electrochemical processes and is apt to estimate the possible performance of materials under real battery operation conditions.

The galvanostatic charge/discharge curves for nonmodified and interface-engineered all-solid-state batteries based on $c-\mathrm{Li}_{6.25} \mathrm{Al}_{0.25} \mathrm{La}_{3} \mathrm{Zr}_{2} \mathrm{O}_{12}$ electrolyte and $\mathrm{Li}_{4} \mathrm{Ti}_{5} \mathrm{O}_{12}$ electrode are shown in Figure 5. The cells were cycled between 2.5 and $1.0 \mathrm{~V}$ at $95{ }^{\circ} \mathrm{C}$. Note that the working electrode is always composed of $80 \mathrm{wt} \%$ active material (nanograined $\mathrm{Li}_{4} \mathrm{Ti}_{5} \mathrm{O}_{12} / \mathrm{c}-\mathrm{Li}_{6.25} \mathrm{Al}_{0.25} \mathrm{La}_{3} \mathrm{Zr}_{2} \mathrm{O}_{12}$ composite), 10 wt\% conductive carbon, and $10 \mathrm{wt} \%$ PVDF binder. The nonmodified all-solidstate batteries only showed limited charge/discharge capacities with apparent polarization; see Figure 5a,c. Though the cells were electrochemically active, in most of the cases the delivered capacities did not exceed $\approx 2-3 \mathrm{~A} \mathrm{~h} \mathrm{~kg}^{-1}$, hinting at the possible hampered charge transfer at the electrode-electrolyte interface in the given cell assembly. In contrast, the electrochemical performance is vastly improved for the interface-engineered batteries, Figure 5b,c: Here, the reversible lithiation/delithiation of $\mathrm{Li}_{4} \mathrm{Ti}_{5} \mathrm{O}_{12}$ is clearly visible with distinct charge/discharge plateaus for the interface-engineered all-solid-state batteries based on $\mathrm{c}-\mathrm{Li}_{6.25} \mathrm{Al}_{0.25} \mathrm{La}_{3} \mathrm{Zr}_{2} \mathrm{O}_{12}$, Figure $5 \mathrm{~b}$. The charge/discharge capacities are in the range of $15-20 \mathrm{~A} \mathrm{~h} \mathrm{~kg}^{-1}$ and the degree of polarization is strongly reduced compared to the nonmodified all-solid-state batteries. The improvement achieved with the interface-engineered batteries is also clearly visible in comparison of the potential versus time plots, Figure 5c. To isolate the effect of the porous interface of the interface-engineered cells from the possibly beneficial effect of the second sintering without subsequent polishing in contrast to nonmodified cells, a control sample was prepared by sintering nonmodified pellet with subsequent 2 nd sintering in the same way as for interfaceengineered pellets. Charge/discharge curve of this nonpolished, nonmodified all-solid-state battery with identical cycling conditions are shown in Figure S6 (Supporting Information). Such cells show slightly better performance than the standard nonmodified cells, possibly due to the increased surface roughness induced by the 2nd sintering without subsequent polishing. The achieved capacity, however, is still only a fraction of the one achieved for interface-engineered all-solid-state batteries, proving that the increase in cell performance and capacity of interface-engineered cells can be attributed to their porous interface with graded electrolyte-electrode structure.

The $\mathrm{d} Q / \mathrm{d} V$ plot of an interface-engineered all-solid-state battery obtained from the first galvanostatic charge/discharge curves is displayed in Figure 5d; see Figure S7 (Supporting Information) for subsequent cycles. The oxidation peak appears at $\approx 1.6 \mathrm{~V}$ and the reduction peak is found at $\approx 1.5 \mathrm{~V}$. We 


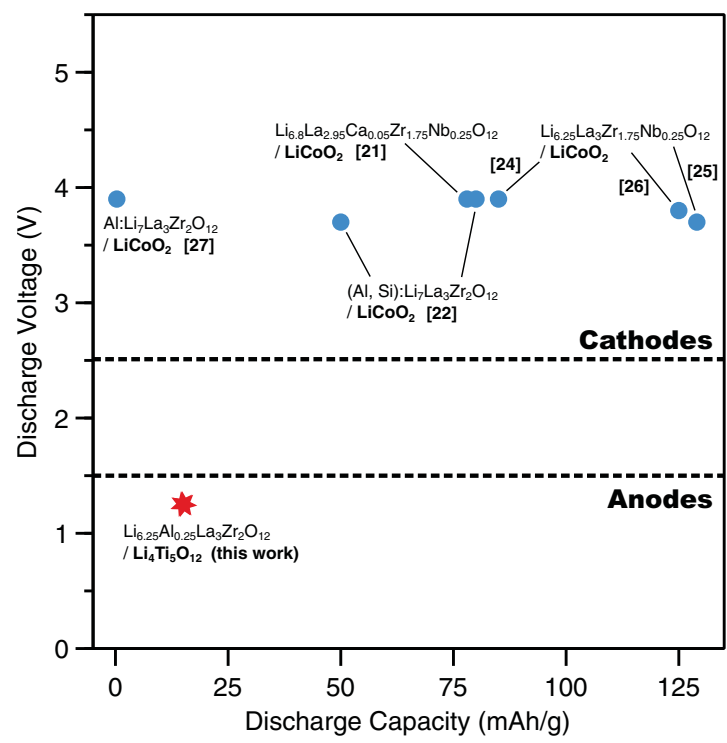

Figure 7. Discharge capacities of all-solid-state batteries with variously doped cubic $\mathrm{Li}_{7} \mathrm{La}_{3} \mathrm{Zr}_{2} \mathrm{O}_{12}$ and different electrode materials from literature are displayed. Blue data points show samples with $\mathrm{LiCoO}_{2}$ electrodes measured at room temperature and the red point shows the result of this work using nanograined $\mathrm{Li}_{4} \mathrm{Ti}_{5} \mathrm{O}_{12}$ electrodes measured at $95^{\circ} \mathrm{C}$. It should be noted that discharge capacities of cells in literature have been mostly obtained employing vacuum techniques, i.e., PLD, for the deposition of electrodes.

highlight that the achieved potentials are comparable to liquid electrolyte battery systems operating on $\mathrm{Li}_{4} \mathrm{Ti}_{5} \mathrm{O}_{12}$ and confirm the reversible insertion and extraction of lithium ions for the all-solid-state battery assembly presented. ${ }^{[4]}$ We also note that the polarization is still existent, which can be inferred from the broadness of peaks, especially in the case of the reduction process, see Figure $5 \mathrm{~d}$. For further understanding of the kinetic limitations and cycling stability of the system, rate capability tests for interface-engineered all-solid-state batteries based on c- $\mathrm{Li}_{6.25} \mathrm{Al}_{0.25} \mathrm{La}_{3} \mathrm{Zr}_{2} \mathrm{O}_{12}$ were performed, see Figure $5 \mathrm{e}$. The discharge capacities in the range of $\approx 16,8$, and $3 \mathrm{~A} \mathrm{~h} \mathrm{~kg}^{-1}$ are obtained at the rates of 2,4 , and $8 \mathrm{~A} \mathrm{~kg}^{-1}$, respectively. Notably, at the 18th cycle, the capacity recovers to $14 \mathrm{~A} \mathrm{~h} \mathrm{~kg}^{-1}$ when the discharge rate is switched back from 8 to $2 \mathrm{~A} \mathrm{~kg}^{-1}$. Clearly, the capacities drastically decrease with increasing rate in line with the kinetic limitations in all-solid-state batteries but the reversible cycling of $\mathrm{Li}_{4} \mathrm{Ti}_{5} \mathrm{O}_{12}$ with c- $\mathrm{Li}_{6.25} \mathrm{Al}_{0.25} \mathrm{La}_{3} \mathrm{Zr}_{2} \mathrm{O}_{12}$ solid electrolyte could be demonstrated at a relatively higher discharge rate of $8 \mathrm{~A} \mathrm{~kg}^{-1}$. Besides, the cycling is fairly stable within the limit of operation conditions and tapped capacities here, as a discharge capacity of $13 \mathrm{~A} \mathrm{~h} \mathrm{~kg}^{-1}$ is still delivered at the 25 th cycle, indicating that the lithiation/delithiation of $\mathrm{Li}_{4} \mathrm{Ti}_{5} \mathrm{O}_{12}$ at $95{ }^{\circ} \mathrm{C}$ against c- $\mathrm{Li}_{6.25} \mathrm{Al}_{0.25} \mathrm{La}_{3} \mathrm{Zr}_{2} \mathrm{O}_{12}$ could be mostly stable. Notably, this is in contrast to some cathode materials (e.g., $\mathrm{LiCoO}_{2}$ ) that are shown to react and form secondary phases (e.g., $\mathrm{La}_{2} \mathrm{CoO}_{4}$ ) with LLZO. ${ }^{[22]}$ The postmortem analysis performed on the cycled cells further confirms this point: SEM images and EDX spectra over the cross-section of cells are displayed in Figure 6. Here, we indicate the EDX probing at six localities with point one being a reference taken at the electrode, and points 2-6 taken at the nearby regions of interface to the solid electrolyte within the battery cell. The spectrum of the marked regions did not reveal any new phases containing titanium at the electrodeelectrolyte interphase, see Figure 6 and Figure S8 (Supporting Information) for further details; however, the formation of other solid electrolyte interphases without titanium cannot be excluded and requires attention in follow-up work. Nevertheless, within the limits of techniques and investigations in this study, it can be still stated that c- $\mathrm{Li}_{6.25} \mathrm{Al}_{0.25} \mathrm{La}_{3} \mathrm{Zr}_{2} \mathrm{O}_{12}$ could be a suitable solid electrolyte for the Li-ion battery operations in combination with the anode material $\mathrm{Li}_{4} \mathrm{Ti}_{5} \mathrm{O}_{12}$ even at relatively high temperatures (as here tested at $95^{\circ} \mathrm{C}$ ).

We summarize our battery performances and characteristics of the synthesized $c-\mathrm{Li}_{6.25} \mathrm{Al}_{0.25} \mathrm{La}_{3} \mathrm{Zr}_{2} \mathrm{O}_{12}$ electrolyte and $\mathrm{Li}_{4} \mathrm{Ti}_{5} \mathrm{O}_{12}$ anode and compare these to all-solid-state batteries based on LLZO garnet electrolytes in literature, see Figure 7 and Table 1. Li-ionic conductivities and relative densities for

Table 1. Literature overview of all-solid-state batteries based on $\mathrm{Li}_{7} \mathrm{La}_{3} \mathrm{Zr}_{2} \mathrm{O}_{12}$ garnet electrolytes, showing electrolyte composition, ionic conductivity and density, electrode material and deposition method, and electrochemical battery performances.

\begin{tabular}{|c|c|c|c|c|c|c|c|c|}
\hline \multicolumn{3}{|c|}{ Electrolyte } & \multicolumn{2}{|r|}{ Electrode } & \multicolumn{4}{|c|}{ Battery performance } \\
\hline Electrolyte material & $\begin{array}{c}\text { Li-ion conductivity } \\
{\left[\mathrm{S} \mathrm{cm}^{-1}\right]} \\
\end{array}$ & $\begin{array}{c}\text { Relative } \\
\text { density [\%] }\end{array}$ & $\begin{array}{c}\text { Electrode } \\
\text { material }\end{array}$ & Deposition method ${ }^{\text {a) }}$ & $\begin{array}{l}\text { Discharge } \\
\text { voltage [V] }\end{array}$ & $\begin{array}{c}\text { Discharge capacity } \\
{\left[\mathrm{mAh} \mathrm{g}^{-1}\right]}\end{array}$ & $\begin{array}{c}\text { Multiple } \\
\text { cycles }[>20]\end{array}$ & Reference \\
\hline $\mathrm{Li}_{6.75} \mathrm{La}_{3} \mathrm{Zr}_{1.75} \mathrm{Nb}_{0.25} \mathrm{O}_{12}$ & $1.67 \times 10^{-3}$ & $89-92$ & $\mathrm{LiCoO}_{2}$ & PLD & 3.7 & 129 & $x$ & {$[25]$} \\
\hline $\mathrm{Li}_{6.75} \mathrm{La}_{3} \mathrm{Zr}_{1.75} \mathrm{Nb}_{0.25} \mathrm{O}_{12}$ & $8 \times 10^{-4}$ & $89-92$ & $\mathrm{LiCoO}_{2}$ & PLD & 3.8 & 125 & & [26] \\
\hline $\mathrm{Li}_{6.75} \mathrm{La}_{3} \mathrm{Zr}_{1.75} \mathrm{Nb}_{0.25} \mathrm{O}_{12}$ & $1.23 \times 10^{-3}$ & $89-92$ & $\mathrm{LiCoO}_{2}$ & Screen printing & 3.9 & 85 & & [24] \\
\hline $\mathrm{Li}_{7} \mathrm{La}_{3} \mathrm{Zr}_{2} \mathrm{O}_{12}(1.7 \mathrm{wt} \% \mathrm{Al}, 0.1 \mathrm{wt} \% \mathrm{Si})$ & $6.8 \times 10^{-4}$ & 93 & $\mathrm{LiCoO}_{2}$ & PLD & 3.75 & 50 & & [22] \\
\hline $\mathrm{Li}_{7} \mathrm{La}_{3} \mathrm{Zr}_{2} \mathrm{O}_{12}(1.7 \mathrm{wt} \% \mathrm{Al}, 0.1 \mathrm{wt} \% \mathrm{Si})$ & $6.8 \times 10^{-4}$ & 93 & $\mathrm{LiCoO}_{2}$ & PLD with Nb interlayer & 3.9 & 80 & $x$ & [22] \\
\hline $\mathrm{Li}_{6.8} \mathrm{La}_{2.95} \mathrm{Ca}_{0.05} \mathrm{Zr}_{1.75} \mathrm{Nb}_{0.25} \mathrm{O}_{12}$ & $4.8 \times 10^{-4}$ & 90 & $\mathrm{LiCoO}_{2}$ & $\begin{array}{l}\text { Copressing followed by } \\
\text { cosintering }\end{array}$ & 3.9 & 75 & & [21] \\
\hline $\begin{array}{l}\mathrm{Li}_{7} \mathrm{La}_{3} \mathrm{Zr}_{2} \mathrm{O}_{12} \text { (uncontrolled Al doping } \\
\text { from crucible) }\end{array}$ & $1.8 \times 10^{-4}$ & - & $\mathrm{LiCoO}_{2}$ & Sol-gel & 3.9 & 0.3 & & [27] \\
\hline $\mathrm{Li}_{6.25} \mathrm{Al}_{0.25} \mathrm{La}_{3} \mathrm{Zr}_{2} \mathrm{O}_{12}$ & $5.0 \times 10^{-4}$ & 87 & $\mathrm{Li}_{4} \mathrm{Ti}_{5} \mathrm{O}_{12}$ & $\begin{array}{l}\text { Slurry coating on sintered } \\
\text { pellet assembly }\end{array}$ & 1.25 & $15\left(95^{\circ} \mathrm{C}\right)$ & $x$ & This work \\
\hline
\end{tabular}

a)PLD: pulsed laser deposition. 
LLZO pellets and tested electrode materials are summarized relative to the processing and deposition methods, average discharge potentials and capacities, and relative cycling stabilities of the cells. Till date, most of the work published on all-solidstate batteries based on LLZO garnet electrolytes focus on the cathode material, $\mathrm{LiCoO}_{2}$, as electrode, see Figure 7. Here, the obtained capacities vary greatly in the range of $0.3-129 \mathrm{~A} \mathrm{~h} \mathrm{~kg}^{-1}$ depending on the deposition method of the cathode material: Capacities close to theoretical values $\left(\approx 140 \mathrm{~A} \mathrm{~h} \mathrm{~kg}^{-1}\right)$ are primarily achieved through vacuum-based thin film depositions of the cathode, namely, with pulsed laser deposition, giving capacities of 80-129 A h kg-1. ${ }^{[22,25,26]}$ Capacities of 75-85 $\mathrm{A} \mathrm{h} \mathrm{kg}^{-1}$ were achieved by screen printing or copressing of the cathode followed by an annealing step enabled by sintering aids in either the electrolyte or the cathode. ${ }^{[21,24]}$ The only work using casting of the cathode without cosintering in the form of a solgel process reported capacities below $1 \mathrm{~A} \mathrm{~h} \mathrm{~kg}^{-1}$.[27] Compared to the previous studies, the investigation of the here presented low potential electrode material, $\mathrm{Li}_{4} \mathrm{Ti}_{5} \mathrm{O}_{12}$, and the use of direct casting methods on LLZO pellets resulting in capacities of up to $20 \mathrm{~A} \mathrm{~h} \mathrm{~kg}^{-1}$ are unique. Based on the careful literature comparison, Figure 7, we conclude that the presented results show first alternatives of now full ceramic anodes assembled for allsolid-state battery assemblies based on Li-garnet structures. For future full ceramic cells this is an important step forward as it first demonstrates the applicability of a commercially available anode material in addition to the state-of-the-art cathodes tested for garnet-based all-solid-state batteries. Varying the thickness and morphology of the anode material, and finding an optimum processing ratio between the electrode and the solid electrolyte materials for the interface is outlined to further boost performances in the future close to theoretical capacitances of the anode material presented.

\section{Conclusion}

All-solid-state batteries based on garnet-type c- $\mathrm{Li}_{6.25} \mathrm{Al}_{0.25} \mathrm{La}_{3} \mathrm{Zr}_{2} \mathrm{O}_{12}$ solid electrolytes were successfully fabricated and tested, combining for the first time an anode material $\left(\mathrm{Li}_{4} \mathrm{Ti}_{5} \mathrm{O}_{12}\right)$ and Li-metal counter electrodes. Here, we suggest a novel ceramic development route to design an enhanced $\mathrm{Li}^{+}$ transfer at the electrode-electrolyte interface using an interface-engineered all-solid-state battery cell structure based on a nanoporous garnet electrolyte interface structure in which the anode material is cast to reach high interfacial surface area and contact points. To demonstrate the feasibility of the newly suggested battery cell assembly, a model example of two cells is presented, whereby the first one is a traditionally casted and flat assembly and the second reveals an interface engineering of the c- $\mathrm{Li}_{6.25} \mathrm{Al}_{0.25} \mathrm{La}_{3} \mathrm{Zr}_{2} \mathrm{O}_{12}-\mathrm{Li}_{4} \mathrm{Ti}_{5} \mathrm{O}_{12}$ interface for battery testing.

From electrochemical investigations of the two model batteries with casted electrodes, the lowered impedances and improved capacities of the interface-engineered all-solidstate batteries reveal clear improvement toward traditional flat casting. Importantly, scanning electron microscopy and electrochemical impedance spectroscopy investigations on the interface-engineered all-solid-state batteries based on c- $\mathrm{Li}_{6.25} \mathrm{Al}_{0.25} \mathrm{La}_{3} \mathrm{Zr}_{2} \mathrm{O}_{12}$ revealed an intimate embedding of the nanograined $\mathrm{Li}_{4} \mathrm{Ti}_{5} \mathrm{O}_{12}$ into the porous electrolyte interlayer and thereby drastically reduced cell resistances compared to nonmodified cells. When combined with Li-metal counter electrodes, the battery cells could be reversibly cycled in low potential ranges $(\approx 1.5 \mathrm{~V})$ showing specific capacities of up to $20 \mathrm{~A} \mathrm{~h} \mathrm{~kg}^{-1}$ (at $95^{\circ} \mathrm{C}$ ). These findings point out novel perspectives to use commercially available nanograined $\mathrm{Li}_{4} \mathrm{Ti}_{5} \mathrm{O}_{12}$ as anode material combined with Li-garnet solid electrolytes. Clearly defined oxidation and reduction potentials of interfaceengineered all-solid-state batteries verified proper $\mathrm{Li}^{+}$insertion and extraction processes during cycling and rate capability tests showed that they can be cycled for more than 25 cycles with relatively higher current rates of up to $8 \mathrm{~A} \mathrm{~kg}^{-1}$.

To succeed in the low temperature assembly of the interface-engineered battery cells, the garnet phase is required to be in a small grain size to ensure a good physical contact between the nanograined electrode and electrolyte constituents. For this, we discussed the use of the low temperature synthesis-processing route demonstrated to make submicrometer $\mathrm{c}-\mathrm{Li}_{6.25} \mathrm{Al}_{0.25} \mathrm{La}_{3} \mathrm{Zr}_{2} \mathrm{O}_{12}$ particles at temperatures as low as $650{ }^{\circ} \mathrm{C}$. Ceramic pellet structures of c- $\mathrm{Li}_{6.25} \mathrm{Al}_{0.25} \mathrm{La}_{3} \mathrm{Zr}_{2} \mathrm{O}_{12}$ were obtained at $1075{ }^{\circ} \mathrm{C}$ with relative densities of $90 \pm 3 \%$ and of high bulk ionic conductivities of $\approx 0.5 \times 10^{-3} \mathrm{~S} \mathrm{~cm}^{-1}$ at ambient with an activation energy of $0.28 \pm 0.01 \mathrm{eV}$.

Through this work, we demonstrate the first successful assembly of the anode material $\mathrm{Li}_{4} \mathrm{Ti}_{5} \mathrm{O}_{12}$ in combination with c- $\mathrm{Li}_{6.25} \mathrm{Al}_{0.25} \mathrm{La}_{3} \mathrm{Zr}_{2} \mathrm{O}_{12}$ garnet structures and reveal its battery operations to be employed in full ceramic all-solid-state batteries. The model experiment also displays the importance to engineer a suited ceramic interfacial structure with augmented contact points between the electrodes and the electrolyte to assure a proper $\mathrm{Li}^{+}$-transfer during charge and discharge cycles, for which we provide hands-on ceramic processing guidance for the all-solid-state Li-ion batteries.

\section{Experimental Section}

Synthesis, Powder, and Pellet Processing of the $c-\mathrm{Li}_{6.25} \mathrm{Al}_{0.25} \mathrm{La}_{3} \mathrm{Zr}_{2} \mathrm{O}_{12}$ Solid Electrolyte: For the synthesis of cubic garnet particles of the composition c- $\mathrm{Li}_{6.25} \mathrm{Al}_{0.25} \mathrm{La}_{3} \mathrm{Zr}_{2} \mathrm{O}_{12}$ stoichiometric amounts of $\mathrm{LiNO}_{3}$ (99\% Alfa Aesar), Al $\left(\mathrm{NO}_{3}\right)_{3} \cdot 9 \mathrm{H}_{2} \mathrm{O}$ (99\%, Fluka Chemika), La $\left(\mathrm{NO}_{3}\right)_{3} \cdot 6\left(\mathrm{H}_{2} \mathrm{O}\right)(99.9 \%$, Alfa Aesar), and zirconium(IV) acetylacetonate $(98 \% \mathrm{abcr})$ were dissolved in a water/ethanol mixture at temperatures of $70{ }^{\circ} \mathrm{C}$. To avoid possible Li-loss during calcination and sintering, the lithium precursor was taken in a slight excess of $10 \mathrm{wt} \%$ relative to the other precursors. The solvent was left to evaporate overnight at $95{ }^{\circ} \mathrm{C}$ to obtain a dry xerogel, which was ground in a mortar and calcined in a vertical tube furnace at $650{ }^{\circ} \mathrm{C}$ for $15 \mathrm{~h}$ in alumina crucibles under a constant synthetic airflow. Calcination directly yielded the cubic phase $c-\mathrm{Li}_{6.25} \mathrm{Al}_{0.25} \mathrm{La}_{3} \mathrm{Zr}_{2} \mathrm{O}_{12}$, which was ground to a fine powder in a mortar for further processing.

c- $\mathrm{Li}_{6.25} \mathrm{Al}_{0.25} \mathrm{La}_{3} \mathrm{Zr}_{2} \mathrm{O}_{12}$ green body pellets (of $1-2 \mathrm{~mm}$ thickness and 11 or $13 \mathrm{~mm}$ diameter) were prepared by uniaxial pressing with a pressure of $35 \mathrm{kN}$ for $150 \mathrm{~s}$, followed by isostatic pressing at a pressure of $1000 \mathrm{kN}$ for $4 \mathrm{~min}$. The powder pellets obtained this way were polished with P2000 sand paper to remove surface impurities and afterward sintered in a horizontal tube furnace at $1070{ }^{\circ} \mathrm{C}$ for $10 \mathrm{~h}$ under $\mathrm{O}_{2}$ atmosphere with a heating/cooling rate of $4{ }^{\circ} \mathrm{C} \mathrm{min}{ }^{-1}$. Alumina crucibles were used for all sintering steps, and the pellets were covered with parent powder to prevent $\mathrm{Li}$ loss during sintering.

During all of the synthesis steps, the gel powder, calcined powder, and sintered pellets of $\mathrm{c}-\mathrm{Li}_{6.25} \mathrm{Al}_{0.25} \mathrm{La}_{3} \mathrm{Zr}_{2} \mathrm{O}_{12}$ were stored in glass vials 
flushed with nitrogen or in an Ar-filled glovebox to prevent reaction with humidity at all times.

Interface-Engineering of the Solid Electrolyte and All-Solid-State Battery Assemblies: Two types of battery cells were processed through this study varying in their electrode-electrolyte interfacial microstructures:

i. Nonmodified Cells: For nonmodified all-solid-state batteries, c$\mathrm{Li}_{6.25} \mathrm{Al}_{0.25} \mathrm{La}_{3} \mathrm{Zr}_{2} \mathrm{O}_{12}$ pellets $\left(\approx 1 \mathrm{~cm}^{2}\right)$ were polished down with $\mathrm{P} 1200$ sandpaper to a thickness of $360 \pm 20 \mu \mathrm{m}$ and dried at $100{ }^{\circ} \mathrm{C}$ under vacuum. An electrode-electrolyte mixture was prepared by mixing carbon coated nanograined $\mathrm{Li}_{4} \mathrm{Ti}_{5} \mathrm{O}_{12}$ (Life Power, Johnson Matthey) and $\mathrm{c}-\mathrm{Li}_{6.25} \mathrm{Al}_{0.25} \mathrm{La}_{3} \mathrm{Zr}_{2} \mathrm{O}_{12}$ powder in the weight ratio $1: 1$ in an agate mortar. In a second step, $80 \mathrm{wt} \%$ of this electrode-electrolyte mixture (active material) was mixed with $10 \mathrm{wt} \%$ conductive carbon (Super $\mathrm{P}$ Li Timcal) and 10 wt\% PVDF (Sigma-Aldrich) binder and dispersed in THF (tetrahydrofuran)/toluene (4:1 vol. ratio) by ultrasonication to obtain an electrode slurry. The electrode slurry was cast onto the dried c- $\mathrm{Li}_{6.25} \mathrm{Al}_{0.25} \mathrm{La}_{3} \mathrm{Zr}_{2} \mathrm{O}_{12}$ pellets and dried again at $100^{\circ} \mathrm{C}$ under vacuum, yielding $\approx 4 \mathrm{mg}$ of electrode material.

ii. Interface-Engineered Cells: The interface-engineered batteries were processed by a route utilizing sacrificial organic templates, see Figure S1 (Supporting Information). For the interface modification of all-solid-state batteries, first, a slurry of $\mathrm{c}-\mathrm{Li}_{6.25} \mathrm{Al}_{0.25} \mathrm{La}_{3} \mathrm{Zr}_{2} \mathrm{O}_{12} /$ starch was prepared by mixing $\mathrm{c}-\mathrm{Li}_{6.25} \mathrm{Al}_{0.25} \mathrm{La}_{3} \mathrm{Zr}_{2} \mathrm{O}_{12}$ powder and starch (Patissier, Migros) in the weight ratio 3:1 in an agate mortar, which was then ultrasonically dispersed $(50 \mathrm{mg}$ of the mixture per $1 \mathrm{~mL}$ of solvent) in THF/toluene (4:1 vol. ratio) for at least $1 \mathrm{~h}$. Second, the sintered pellets of $\mathrm{c}-\mathrm{Li}_{6.25} \mathrm{Al}_{0.25} \mathrm{La}_{3} \mathrm{Zr}_{2} \mathrm{O}_{12}$ were polished down with $\mathrm{P} 1200$ sandpaper to a thickness of $360 \pm 20 \mu \mathrm{m}$ and dried under vacuum in a Schlenk tube for $1 \mathrm{~h}$ at $100^{\circ} \mathrm{C}$. Then, for the slurry deposition, three droplets of the c- $\mathrm{Li}_{6.25} \mathrm{Al}_{0.25} \mathrm{La}_{3} \mathrm{Zr}_{2} \mathrm{O}_{12} /$ starch slurry were dropped onto the pellet with a Pasteur pipette and the solvent was left to evaporate at room temperature for a few minutes. This procedure was repeated three times to adapt the desired thickness. Subsequently, the pellet with the slurry on top was dried for $1 \mathrm{~h}$ at $100^{\circ} \mathrm{C}$ under vacuum. The pellet was then sintered in a 2 nd step in a tube furnace at $1070^{\circ} \mathrm{C}$ for $10 \mathrm{~h}$ under an $\mathrm{O}_{2}$ rich atmosphere; viz. in the same way as the $1 \mathrm{st}$ sintering step of the pellet green bodies had been processed. To control the burning-off of the starch, the heating rate was limited to $7^{\circ} \mathrm{C} \mathrm{min}^{-1}$ up to $600^{\circ} \mathrm{C}$ during sintering. In all steps, alumina crucibles were used and the pellets were covered in parent powder during sintering. The casting of the $\mathrm{Li}_{4} \mathrm{Ti}_{5} \mathrm{O}_{12}$ electrode was done in the same way as the one for nonmodified cells involving the direct casting of electrode-electrolyte composite slurry consisting of $\mathrm{Li}_{4} \mathrm{Ti}_{5} \mathrm{O}_{12}, c-\mathrm{Li}_{6.25} \mathrm{Al}_{0.25} \mathrm{La}_{3} \mathrm{Zr}_{2} \mathrm{O}_{12}$ powder, conductive carbon, and PVDF binder.

Both types of all-solid-state battery geometries, namely the nonmodified cells and the interface-engineered cells, were assembled for electrochemical testing in Swagelok-type cells in an Ar-filled glovebox. For this, Li-metal counter electrodes were prepared from a $0.75 \mathrm{~mm}$ thick Li foil (Alfa Aesar).

To isolate the effect of the porous interface of the interface-engineered pellets, a control sample with nonmodified interface was prepared by polishing a dense $\mathrm{c}-\mathrm{Li}_{6.25} \mathrm{Al}_{0.25} \mathrm{La}_{3} \mathrm{Zr}_{2} \mathrm{O}_{12}$ pellet to a thickness of $340 \mu \mathrm{m}$ and subsequent sintering embedded in parent powder for a second time in the same way as for interface-engineered samples. No polishing was done after the 2 nd sintering before the electrode slurry was deposited and the battery was assembled as usual.

Chemical and Structural Characterization: Powder X-ray diffraction patters of the powder samples were recorded using a STOE Stadi $P$ diffractometer equipped with a germanium monochromator and $\mathrm{CuK}_{\alpha 1}$ radiation operated at $35 \mathrm{~mA}$ and $35 \mathrm{kV}$.

Dilatometry curves were measured using a TA Instruments DIL 806 optical dilatometer to access the optimized sintering conditions. For this, c- $\mathrm{Li}_{6.25} \mathrm{Al}_{0.25} \mathrm{La}_{3} \mathrm{Zr}_{2} \mathrm{O}_{12}$ powder was pressed into a green body pellet as described above and heated with a constant heating rate of $10^{\circ} \mathrm{C} \mathrm{min}{ }^{-1}$.

SEM analysis of samples were recorded with a Zeiss Gemini 1530 operated at $5 \mathrm{kV}$. EDX spectroscopy measurement was performed on postmortem cleaved cross-sections of cycled cells with a UltraDry II (Thermo Fisher Scientific) equipped on the SEM.

Electrochemical Impedance and All-Solid-State Battery Performance Tests: For AC electrochemical impedance studies, sintered c- $\mathrm{Li}_{6.25} \mathrm{Al}_{0.25} \mathrm{La}_{3} \mathrm{Zr}_{2} \mathrm{O}_{12}$ pellets were polished down with $\mathrm{P} 1200$ sandpaper to the desired thickness of $0.5-1.0 \mathrm{~mm}$. Pt was sputtered on both sides of the pellets (BAL-TEC, SCD 050 Sputter-Coater, thickness $\approx 14 \mathrm{~nm}$ ) and $\mathrm{Pt}$ wires were sandwiched between two layers of Pt paste (C $3605 \mathrm{~S}$, Heraeus). The Pt wires were fixed using ceramic binder (Thermokit Roth, Carl Roth). After Pt paste and ceramic binder application, the pellets were dried at $300{ }^{\circ} \mathrm{C}$ for $10 \mathrm{~min}$ and at $100{ }^{\circ} \mathrm{C}$ for $30 \mathrm{~min}$, respectively. Electrochemical impedance spectra were recorded with a Gamry Reference 600 potentiostat/galvanostat/ZRA (zero resistance ammeter) in the frequency range of $1 \mathrm{MHz}$ to $0.1 \mathrm{~Hz}$ with an alternating voltage of $10 \mathrm{mV}$ and the spectra were analyzed using the ZView software. ${ }^{[4]}$ High temperature measurements were done in a tube furnace under a constant Ar atmosphere to avoid exposure of the electrolyte pellets to humidity. Impedance measurements of full cells were done at $95{ }^{\circ} \mathrm{C}$ in the as-assembled state with an alternating voltage of $50 \mathrm{mV}$ versus their open circuit potential.

For battery performance tests, nonmodified all-solid-state batteries and interface-engineered all-solid-state batteries were discharged/ charged in galvanostatic modes at $95{ }^{\circ} \mathrm{C}$ between 1.0 and $2.5 \mathrm{~V}$ at current rates of 2-8 $\mathrm{A} \mathrm{kg}^{-1}$.

\section{Supporting Information}

Supporting Information is available from the Wiley Online Library or from the author.

\section{Acknowledgements}

J.v.d.B. and S.A. contributed equally to this work and should be considered co-first authors. The authors thank Competence Center Energy and Mobility (CCEM) and Alstom for funding of the projects: Proposal 911 "All Solid State Li-lon Batteries based on New Ceramic Li-Ion Electrolytes" and SP-ESC-A 03-14, ETH Zürich Foundation "All Solid State Li+ Batteries with high Thermal Operation Window," respectively.

Received: April 7, 2016

Revised: May 6, 2016

Published online: July 12, 2016

[1] J. M. Tarascon, M. Armand, Nature 2001, 414, 359.

[2] B. Diouf, R. Pode, Renewable Energy 2015, 76, 375.

[3] J. Liu, Adv. Funct. Mater. 2013, 23, 924.

[4] X. Ji, K. T. Lee, L. F. Nazar, Nat. Mater. 2009, 8, 500.

[5] S. Afyon, D. Kundu, A. J. Darbandi, H. Hahn, F. Krumeich, R. Nesper, J. Mater. Chem. A 2014, 2, 18946.

[6] S. Afyon, M. Worle, R. Nesper, Angew. Chem., Int. Ed. 2013, 52, 12541.

[7] A. Perea, K. Zaghib, D. Bélanger, J. Mater. Chem. A 2015, 3, 2776

[8] S. Afyon, F. Krumeich, C. Mensing, A. Borgschulte, R. Nesper, Sci. Rep. 2014, 4, 7113.

[9] P. L. Moss, R. Fu, G. Au, E. J. Plichta, Y. Xin, J. P. Zheng, J. Power Sources 2003, 124, 261.

[10] D. Larcher, J. M. Tarascon, Nat. Chem. 2015, 7, 19.

[11] Y. X. Wang, B. Liu, Q. Y. Li, S. Cartmell, S. Ferrara, Z. Q. D. Deng, J. Xiao, J. Power Sources 2015, 286, 330.

[12] J. F. M. Oudenhoven, L. Baggetto, P. H. L. Notten, Adv. Energy Mater. 2011, 1, 10. 
[13] V. Thangadurai, S. Narayanan, D. Pinzaru, Chem. Soc. Rev. 2014, 43, 4714.

[14] R. Murugan, V. Thangadurai, W. Weppner, Angew. Chem., Int. Ed. Engl. 2007, 46, 7778.

[15] C. A. Geiger, E. Alekseev, B. Lazic, M. Fisch, T. Armbruster, R. Langner, M. Fechtelkord, N. Kim, T. Pettke, W. Weppner, Inorg. Chem. 2011, 50, 1089.

[16] N. Bernstein, M. D. Johannes, K. Hoang, Phys. Rev. Lett. 2012, 109, 205702.

[17] W. Gu, M. Ezbiri, R. P. Rao, M. Avdeev, S. Adams, Solid State lonics 2015, 274, 100

[18] S. Afyon, F. Krumeich, J. L. M. Rupp, J. Mater. Chem. A 2015, 3, 18636.

[19] H. El Shinawi, J. Janek, J. Power Sources 2013, 225, 13.

[20] D. Rettenwander, P. Blaha, R. Laskowski, K. Schwarz, P. Bottke, M. Wilkening, C. A. Geiger, G. Amthauer, Chem. Mater. 2014, 26, 2617.

[21] S. Ohta, J. Seki, Y. Yagi, Y. Kihira, T. Tani, T. Asaoka, J. Power Sources 2014, 265, 40

[22] T. Kato, T. Hamanaka, K. Yamamoto, T. Hirayama, F. Sagane, M. Motoyama, Y. Iriyama, J. Power Sources 2014, 260, 292.

[23] C.-W. Ahn, J.-J. Choi, J. Ryu, B.-D. Hahn, J.-W. Kim, W.-H. Yoon, J.-H. Choi, J.-S. Lee, D.-S. Park, J. Power Sources 2014, 272, 554.

[24] S. Ohta, S. Komagata, J. Seki, T. Saeki, S. Morishita, T. Asaoka, J. Power Sources 2013, 238, 53.

[25] S. Ohta, T. Kobayashi, J. Seki, T. Asaoka, J. Power Sources 2012, 202, 332.

[26] S. Ohta, T. Kobayashi, T. Asaoka, J. Power Sources 2011, 196, 3342.

[27] M. Kotobuki, H. Munakata, K. Kanamura, Y. Sato, T. Yoshida, J. Electrochem. Soc. 2010, 157, A1076.

[28] R. Sudo, Y. Nakata, K. Ishiguro, M. Matsui, A. Hirano, Y. Takeda, O. Yamamoto, N. Imanishi, Solid State lonics 2014, 262, 151.

[29] J. Awaka, A. Takashima, K. Kataoka, N. Kijima, Y. Idemoto, J. Akimoto, Chem. Lett. 2011, 40, 60.
[30] J. Awaka, N. Kijima, H. Hayakawa, J. Akimoto, J. Solid State Chem. 2009, 182, 2046.

[31] E. Rangasamy, J. Wolfenstine, J. Sakamoto, Solid State lonics 2012 206, 28.

[32] A. Düvel, A. Kuhn, L. Robben, M. Wilkening, P. Heitjans, J. Phys Chem. C 2012, 116, 15192.

[33] Y. Jin, P. J. McGinn, J. Power Sources 2011, 196, 8683.

[34] L. Cheng, J. S. Park, H. Hou, V. Zorba, G. Chen, T. Richardson, J. Cabana, R. Russo, M. Doeff, J. Mater. Chem. A 2014, 2, 172.

[35] G. T. Hitz, E. D. Wachsman, V. Thangadurai, J. Electrochem. Soc 2013, 160, A1248.

[36] L. Cheng, W. Chen, M. Kunz, K. Persson, N. Tamura, G. Chen, M. Doeff, ACS Appl. Mater. Interfaces 2015, 7, 2073.

[37] M. A. Huang, T. Liu, Y. F. Deng, H. X. Geng, Y. Shen, Y. H. Lin, C. W. Nan, Solid State lonics 2011, 204, 41.

[38] H. Buschmann, S. Berendts, B. Mogwitz, J. Janek, J. Power Sources 2012, 206, 236.

[39] W. E. Tenhaeff, E. Rangasamy, Y. Y. Wang, A. P. Sokolov, J. Wolfenstine, J. Sakamoto, N. J. Dudney, ChemElectroChem 2014, 1,375 .

[40] J. L. Allen, J. Wolfenstine, E. Rangasamy, J. Sakamoto, J. Power Sources 2012, 206, 315

[41] S. Kumazaki, Y. Iriyama, K.-H. Kim, R. Murugan, K. Tanabe, K. Yamamoto, T. Hirayama, Z. Ogumi, Electrochem. Commun. 2011, 13, 509.

[42] M. Kotobuki, K. Kanamura, Y. Sato, T. Yoshida, J. Power Sources 2011, 196, 7750.

[43] A. Sharafi, H. M. Meyer, J. Nanda, J. Wolfenstine, J. Sakamoto, J. Power Sources 2016, 302, 135.

[44] L. V. Nowack, O. Waser, O. Yarema, V. Wood, RSC Adv. 2013, 3, 15618.

[45] D. Johnson, ZView Software, 3.2c, Scribner Associates, Inc. 2008. 